\title{
Dictynna
}

Dictynna

Revue de poétique latine

13 | 2016

Varia

\section{Resonance: the Sonic Environment of Vergil's Eclogues}

William Fitzgerald

\section{(2) OpenEdition \\ 1 Journals}

\section{Electronic version}

URL: http://journals.openedition.org/dictynna/1292

DOI: 10.4000/dictynna.1292

ISSN: 1765-3142

Electronic reference

William Fitzgerald, « Resonance: the Sonic Environment of Vergil's Eclogues », Dictynna [Online], 13।

2016, Online since 20 December 2016, connection on 10 September 2020. URL : http://

journals.openedition.org/dictynna/1292 ; DOI : https://doi.org/10.4000/dictynna.1292

This text was automatically generated on 10 September 2020 .

\section{(c) $(1) \Theta \Theta$}

Les contenus des la revue Dictynna sont mis à disposition selon les termes de la Licence Creative Commons Attribution - Pas d'Utilisation Commerciale - Pas de Modification 4.0 International. 


\title{
Resonance: the Sonic Environment of Vergil's Eclogues
}

\author{
William Fitzgerald
}

1 In what is surely one of the most bucolic moments in modern cinema. Julie Andrews is observed from a swooping helicopter, frolicking in the hills outside Salzburg as she sings (to full orchestral accompaniment) the words "The hills are alive with the sound of music". These are the words that gave the film its English title, but they are puzzling words. ${ }^{1}$ What is the sound of music? The conductor Sir Thomas Beecham turns puzzlement into joke with his remark that "the English may not like music but they absolutely love the noise it makes". Since music is usually defined as organised sound, the sound (or noise) of music seems to undo what music does. So what, to repeat, is the sound of music? If we follow Julie Andrews, the sound of music is what makes the hills alive, or what the hills are alive with and this, of course, is our link to the pastoral tradition. As music becomes (merely) its own sound, the hills become (somehow) alive. In this case, the pathetic fallacy of pastoral depends on a degrading of music, in which it is heard awry, as though by an alien ear.

One more puzzle presents itself-are the hills alive with the sound of music because Julie Andrews is singing, or does Julie Andrews burst into song because the hills are alive with the sound of music? Does she hear the sounds of nature as music, or do the hills 'hear' her music, but as sound? These alternatives correspond to a topos of pastoral criticism, in which Vergil 's Tityrus teaching the woods to resound (Ecl. 1.5) is read as a revision, or reversal, of Lucretius' shepherds learning their music from nature (DRN 5.1379-87). The direction of the flow is a significant issue of pastoral. ${ }^{2}$ But however we imagine this relationship it is clear that the Eclogues, as the founding text of pastoral, ${ }^{3}$ is preoccupied with both sound and with a hearing that mediates the exchange between humans and nature.

3 In the Eclogues, as Alain Deremetz has stressed, Vergil is giving us a myth of the origin of poetry and his choice of the bucolic form manifests, as Deremetz puts it "la tentative de retrouver le langage poétique original avec le lieu qui lui est propre" (1995.295). The same point is elaborated by Philip Damon when he says that "all successful song 
requires a resonant locale" (1961.283). He goes on "For Vergil, the echo was the main metaphorical link between the shepherd's rural habitat and his poetic inspiration. The sounds that the silvae could produce and the triviae could not were the precondition of pastoral song" (1961.296). As far as the triviae are concerned, Damon is referring to these words in Eclogue 3:

non tu in triviis, indocte, solebas

stridenti miserum stipula disperdere carmen? (Ecl. 3.26-7)

Didn't you (ignoramus!) used to murder a wretched song at the crossroads on a

single screeching pipe?

It is interesting to see that later imitators of this passage have their own versions of the miserable sound, but make no mention of the importance of locale and acoustic.

-they are sped;

And when they list, their lean and flashy songs

Grate on their scrannel pipes of wretched straw. (Milton, Lycidas 122-3)

qui vix stillantes, aride, voces

rumpis et expellis male singultantia verba, (Calpurnius Siculus 6.23-4)

You, who can scarcely break out dripping sounds from your dry throat and force

out your wretchedly halting words.

5 We will return later to Calpurnius' ideal hearing environment, so different from Vergil's. Vergil insists on the importance of locale when he calls his bucolic Muse silvestris (Ecl. 1.2), an adjective for which there is no precedent in Theocritus. The nomination stems from Lucretius' account of the delusions of echo, which cheat the countryfolk into believing that the woods are alive with Fauns and Satyrs (DRN 4.580-594). ${ }^{4}$ Pan (=Roman Silvanus), they say, plays the pipes fistula silvestrem ne cesset fundere Musam (so that the pipe should not cease to pour out the woodland Muse). ${ }^{5}$ The human race, Lucretius comments, is avidum auricularum (greedy for ears, 594).

So the main characteristic of pastoral's proper locale is echo; as Damon puts it, "For Vergil the echo was the main metaphorical link between the shepherd's rural habitat and his poetic inspiration". In fact, echo has, not unreasonably, been taken as the matrix of the sonic aspects of the Eclogues, and the close connection between sound, the 'world' of the Eclogues and the metapoetic dimension of Vergil's pastoral collection has encouraged readers to reflect on the possible implications of poetry as echo. In 1941 Marie Desport found in the echoic sound-world of Vergil's Eclogues a revelation of the " pouvoir incantatoire de la poésie" (1941.281). "Incantation" is a term that links the sound to the efficacy of an utterance, but Desport does not elaborate on that aspect of her term. Though it works well as a description of what makes the poetry 'powerful' there is something restrictive or enclosed about the idea of poetry as incantation. Boyle 1977 takes issue with this aspect of the interpretation of poetry as echo in both Desport and Damon, citing the latter to the effect that "The echo-filled atmosphere helps to inform the Eclogues with the basic admission that the pastoral world is a green thought in a green shade, the product of a sensibility which has consciously excluded the world of fact" (Damon 1961: 128). For Boyle, the Musa silvestris (which he contrasts with a more positively characterized Musa agrestis, Ecl. 6.8) is "trivial, impotent, self-confining and self-confined" (1977: 125). It is ironic that "trivial" is here used to denigrate a kind of poetry that the Eclogues contrasts with what is produced in the triviae, and this discrepancy opens the way for a less "self-confined" version of an echoic poetry, a version which insists on the need for a locale in which the poetry resounds. 
7 More recent treatments of the echoing environment of Vergil's Eclogues have, not surprisingly, seen echo as a figure of allusion, and in Brian Breed's version (2006), this is incorporated into a study of the tension between voice and textuality, in which the search for an authoritative original voice is baffled by the deferrals of textuality :"In the presence of echo the authoritative source in the past recedes from our grasp" (2006: 100). Echo, on this account, is backward-looking, the guarantee of an original voice. ${ }^{6}$ It may be that we only hear the echo, but there really was someone singing, and we missed it. ${ }^{7}$ We could take this version of echo as an emblem of one kind of interpretative enterprise: to recover an original sound, an original meaning, framed as the question "What is being echoed?". As an alternative I suggest that we think of the connection between song and sonic environment in the Eclogues as resonance. Resonance might imply sympathetic vibration, as in expressions like "That resonates with what I am thinking". But it can also be a quality that an utterance possesses, by virtue of which it implies an environment. This can be more forward-looking, as in "Vergil's words resonate across the centuries". I would second Deremetz's statement (1995.289) that Vergil's Eclogues inaugurate a practice (instaurer un pratique), and not simply because, as a matter of fact, later poets took up the pastoral torch but because they are resonant. Resonance connects singing to hearing, both of which are forms of vibration, and this invites us to think of the auditory experience of the Eclogues and its significance. Lucretius castigates his ignorant shepherds as representative of a race that is avidum auricularum (greedy for ears). But in his version of echo, listening nature simply gives back what humans have supplied (and no more). Resonance, by contrast, is sympathetic vibration in which hearing becomes a form of sounding, but sounding in another mode, a mode peculiar to the nature of what is resonating (compare Benjamin on translation, footnote 5).

8 What authority do we have for the term "resonance" in the Eclogues? The Latin word resonare features prominently in the first two Eclogues. ${ }^{8}$ In the first Eclogue resonare is transitive and it describes what Tityrus does to his environment. Meliboeus tells Tityrus, in the fifth line of Eclogue 1,

tu Tityre, lentus in umbra

formosam resonare doces Amaryllida silvas. (Ecl. 1.4-5)

You, Tityrus, relaxed in the shade, teach the woods to resound (with) the beautiful

Amaryllis.

9 And in case we missed the significance of this word it is repeated at the beginning of the second Eclogue, but here it is intransitive-the pastoral environment's resonance. Corydon complains to the cruel Alexis, early in the second Eclogue,

at mecum raucis tua dum vestigia lustro

sole sub ardenti resonant arbusta cicadis. (Ecl.2.12-13)

But with me, as I trace your footprints, the copses resound under the burning sun

to the rasping cicadas.

10 "Echo" does not seem quite right as a translation of resonare here. The OLD has, under section 1: "To produce a prolonged sound or echo, to resound; to call a name repeatedly, to echo the praises of; to make a place echo with sound". Indeed, the difference between these two passages would seem to mark a progression from a unidirectional flow (Tityrus teaches the woods; the woods "resound" Amaryllis) to a multidimensional resonance (the copses resound with me, while I trace your footsteps, under the sun, to the cicadas). ${ }^{9}$ But if we take a closer look at the first passage, it too offers us many ways to hear its resonance. 
11 The line formosam resonare doces Amaryllida silvas, Meliboeus' rueful description of Tityrus' pastoral life, is the quintessence of the Eclogues' sound world. So how do we hear it? We note the resonant metrical duplication of resonare in Amaryllida in which the word Amaryllida adds one syllable to the metrical pattern of resonare; the phrase resonare...Amaryllida lingers in the air. But playing against this mirroring pattern around the central verb (doces) is the resonant unit produced by the two consecutive accusatives Amaryllida silvas (and Amaryllida silvas), which the repeated sequence of vowels (i/y : a) turns into an aural unit. These two words vibrate next to each other in a kind of syntactical zeugma, for silvas is the object of doces in a different sense than Amaryllida is the object of resonare, and perhaps we are persuaded that if the woods can 'resonate' Amaryllis, then Tityrus can teach the woods. It is a persistent trick of the Eclogues to turn syntax (composition-resonare doces) into parallel (resonanceAmaryllida silvas). ${ }^{10}$ Do the woods "sing the praises of the beautiful Amaryllis" or do they echo the words formosa Amaryllis? ${ }^{11}$ If the latter, then it is the words formosa Amaryllis that ring out from this line. What I want to stress about this iconic line is that it is avidum auricularum, to appropriate Lucretius' phrase-it hungers for ears, and that is what makes it resonant.

Turning to the aural environment of Corydon's song in Eclogue 2.12-13, we hear different things. What stands out here are the multiple axes of resonance: the arbusta resound both together with and like Corydon (mecum), under the influence of (sub) the burning sun, to the cicadas (cicadis). If we want to translate mecum with "like me", then we make a metaphor of the "burning" sun, which stands for Corydon's burning loveboth Corydon and the arbusta resonate under the heat, literal and metaphorical. Or maybe Corydon resonates to the cicadas as do the arbusta. But it is hard for a single ear to adopt all the aural perspectives that these lines project.

In these two passages we can identify two kinds of resonance: resonance as parallelism, in which we are invited to attend to the analogical relationships within and between different pairings, ${ }^{12}$ and resonance as the multiplication of responsive axes. Either way, a kind of auditory overload leaves us with what could be called the sound of song, or poetry. On a more basic level, the abundant sonic effects of the Eclogues and their relentless mellifluousness, make us overhear poetry, not in the sense of John Stuart Mill's distinction ("Rhetoric is heard, poetry is overheard", in his 1833 essay "Thoughts on Poetry and its Varieties"') but insofar as our hearing becomes too powerful, so that it baffles sense, and perhaps this is what Marie Desport means by 'le pouvoir incantatoire de la poésie'.

14 In Eclogue 1 Vergil alludes to Lucretius' account of the invention of music through the imitation of nature (DRN 5.1379-87) and Vergil's pastoral world, as others have noted, presents us with a myth of the origins of poetry. Let me bring to the table another "myth" of the origin of poetry to serve as a resonant parallel to Vergil's, this one from the American critic Northrop Frye's Anatomy of Criticism. Frye claims that "the two elements of subconscious association which form the basis for lyrical melos and opsis respectively have never been given names. We may call them, if the terms are thought dignified enough, babble and doodle." (275) To bring Frye's insight into the context of the Eclogues I would say that babble and doodle are not only the subconscious basis, or origin, of the composition of poetry, but also correspond to a certain moment in the hearing (or reading, in the case of doodle) of poetry; babble arises when the play of sound resonates as the sound of sense, as though echoed by a non-human "listener", 
like Vergil's resonant woods. Resonance in this sense is reduction, a degrading that is at the same time the sound that is made by sense when stripped of its communicative function, as though heard by an alien ear.

In the Eclogues there is plenty of babble, by which I mean moments in which the ear, overloaded with sonic impressions, loses touch with meaning and hears only the sound of sense, as the semantic role of words seems to recede before the play of sounds, right from the first line. A Roman reader might have attributed more sense than we do to individual syllables and similar linguistic sounds ${ }^{13}$, so the sound of sense is a notion that might have more, or different, traction in the Roman context. It is no coincidence that the lines of English poetry that are sometimes cited as the most egregious example of sound taking primacy over sense come from a pastoral poem, the Victorian poet Tennyson's 'Come Down O Maid'. This version of the Cyclops' invitation to Galatea in Theocritus' Idyll 11, entices the addressee to come down from the heights to the valleys, and in the final lines invites her to listen. ${ }^{14}$

Sweeter thy voice, but every sound is sweet,

Myriads of rivulets hurrying through the lawn,

The moan of doves in immemorial elms

And murmuring of innumerable bees

The Latin word memor has been recognised in recent years as an icon of intertextuality in Latin poetry, ${ }^{15}$ and we might say that Tennyson's elms are "immemorial" because they resound with the pastoral tradition. But Tennyson's immemorial puts the elms past memory, so that the echoing of poems and poets of the past becomes indistinct: the sound of intertextuality, like the murmuring of innumerable bees. Tennyson cleverly makes it awkward for us to fully pronounce both "murmuring" and "innumerable"; we are not inclined to tell off, or count, one syllable after another in our pronunciation, and so what emerges is a confused but suggestive mumble.

Tennyson's critics hold that here, as elsewhere, he has degenerated into babble. But he is remembering, resonating to, and re-sounding this:

Non insueta gravis temptabunt pabula fetas

nec mala vicini pecoris contagia laedent

......

hinc tibi, quae semper, vicino ab limite saepes

Hyblaeis apibus florem depasta salicti

saepe levi somnum suadebit inire susurro;

hinc alta sub rupe canet frondator ad auras,

nec tamen interea raucae, tua cura, palumbes

nec gemere aeria cessabit turtur ab ulmo.

(Ecl. 1.49-50; 53-8)

No unaccustomed feed will afflict your ailing animals while pregnant, nor will the neighbouring flock harm them with infection. But, as always, the hedge this side, on your neighbour's boundary, will often lull you to sleep with a gentle murmur, as its willow flowers are grazed by bees from Hybla; the pruner will raise his song to the skies under the steep crag, and meanwhile the husky pigeons, your special care, will not cease their moan, nor will the turtledove in the tall elm.

18 Appropriately, the lines that Tennyson is echoing are Meliboeus' description of the continuity of pastoral life for Tityrus, a continuity that is framed in terms of sound. Vergil casts the resonance of the pastoral landscape in lines 53-8 as a positive version of the images of contagion and encroachment that precede it in lines 49-50 (quamvis obducat; non temptabunt...nec contagia laedent), a contrast that moves pastoral resonance away from the self-confinement that worried Boyle. ${ }^{16}$ The point of contact ceases to be 
a source of contagion, and becomes instead a locus from which sound radiates benignly (vicino ab limite) in the form of the bees feeding off the flowers in the boundary hedge, inducing sleep. The singing frondator is surrounded by the continuous and insistent sound of the reduplicated turtur and the repeated trisyllables of the bees (suadebit inire susurro). So the zone of contact between neighbours has been refigured as a locus of benign continuity rather than contagion, and this continuity is made audible in the pun on saepes in the word saepe, a pun that is reinforced by the words quae semper. The continuous buzzing of the bees is matched by the insistent cooing of the doves. The important point here is that the continuation of pastoral life is sonic: the line nec gemere aeria cessabit turtur ab ulmo identifies the in-cessant cooing of the doves with the repetitive hexameter of the Eclogues itself. ${ }^{17}$ Here is Vergil's revision of Lucretius' debunking fistula silvestrem ne cesset (cf nec...cessabit) fundere Musam, cited above.

Once again (as with the line formosam resonare doces Amaryllida silvas), a subtle effect, pitting sound against syntax, is achieved by the parallel, or repetitive, sound and rhythm of nec tamen interea and nec gemere aeria in two elements of a single syntactical unit (nec tamen interea gemere cessabit....); syntax, or composition, is diverted into parallelism, or resonance. ${ }^{18}$ In the parallel sound and metre of nec tamen interea and nec gemere aeria the sound acquires its own structure and plays across the meaning, or creates a new, sonic dimension of meaning. ${ }^{19}$

In line 57 we can note a characteristic 'trick' of Vergil in the Eclogues-the dipthong ae, repeated in saepes, Hyblaeis, is then decomposed as a mellifluous succession in the verb suadebit. Is this babble or doodle, and how much sense can we give to it? The same thing happens with raucae tua cura palumbes: diphthong au in raucae becomes disyllabic and its sequence is reversed in tua and cura, and is then returned to its original sequence in palumbes. Here, we may be inclined to attribute sense to, or interpret, the process by which the raucousness of the doves is mitigated by the cura of Tityrus, insofar as the attention expressed by cura corresponds to a re-hearing of raucae, of which it is almost an anagram.

Though I will not pursue this in detail, we should not forget the strain of the Eclogues that concerns writing, transcription, or Frye's 'doodle'. ${ }^{20}$ In the landscape of the Eclogues the experience of reading is made strange, decomposed. The situation of the lovesick Corydon in Eclogue 2 is a good example, for in the passage I quoted the resonant arbusta provide the accompaniment to Corydon's tracking of Alexis' vestigia: tua dum vestigia lustro (while I scan for your traces, Ecl. 2.12). It is easy enough to see an allegory of reading here as the eye of Corydon scans (lustro) the vestigia of his beloved. For vestigium the OLD has: 6 "any mark or line made by the application of pressure, imprint", and 7 "The visible trace or remnant of something which no longer exists or is present'. In these lines the act of reading is resolved into separate components of sight and sound. Magnified and projected into the landscape, the act of reading is made strange, its fusion of sight and sound is no longer seamless and automatic, but rather a composition, an event with its own drama. The landscape of the Eclogues, the place in which the singing happens, is reverberant-repeating, but in a different mode, the activity of reading poetry in a locale that makes us experience it in alien terms. Metapoetry? Yes, but when noting metapoetry our hermeneutic flow has tended to return us what is familiar: we rest when we have reached the point where we can say, "so it's about poetry". But what is poetry about? How does the resonant environment of 
the Eclogues make us think about poetry's equivalent of "the sound of music" (perhaps "the sound of sense"?)?

The two passages in the first two Eclogues that I have taken as emblematic of Vergil's sound-world share the striking sound word raucus, applied to the doves in Eclogue 1 (57) and the cicadas in Eclogue 2 (12). Is raucus an unpleasant sound? Not as much as the English-speaking reader would suppose. It is often used of the roar or resonance of the sea, for instance, as well as of brass instruments, usually in a military context (OLD $2 \mathrm{~b}$ and 3 respectively). It is, first of all, the sound of a throat, and so potentially of speech, but of a speech that has either degraded in a human speaker (so, "hoarse") or that imitates some aspect of human speech (vibration, for instance) in another mode, as with a brass instrument. In the two appearances of raucus in the passages from Eclogues 1 and 2 that I have cited there is a reciprocity between Tityrus' cura, which provides a pleasant resonance to the raucae doves, and the cicadas of Eclogue 2, who provide a 'raucous' resonance to Corydon's singing. ${ }^{21}$ This reciprocity suggests an exchange between the human and the natural which pivots on a sound that reduces human speech to something that can be shared with nature.

Damon (1961. 293) includes raucus among the characteristic words for sound in the Eclogues which appear in later pastoral to describe a natural sound that is irritating (garrulus, raucus, argutus). ${ }^{22}$ One of his most striking examples is a passage from Calpurnius Siculus' sixth Eclogue, in which Astylus responds to the invitation of Mnasyllus to sit beneath an ilex tree where the Muses have made a couch for them.

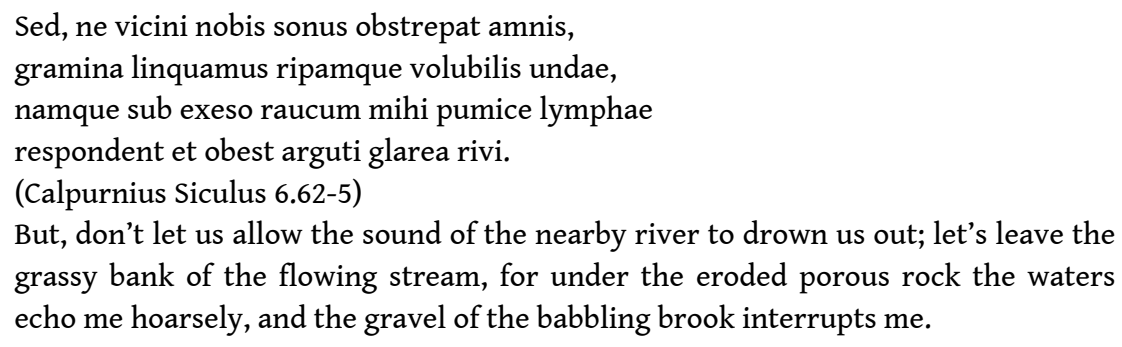

24 Astylus rejects as unpleasant a nature that is responsive to human voice (raucum respondent, 64-5). His fellow singer, Lycidas, suggests that they move from the riverside to the more conducive sonic environment of a cave, and when they arrive there Mnasyllus announces that they have exchanged noise for the silence of the cave (tacito sonitum mutavimus antro, 70). For Calpurnius' Astylus, the sound of the environment (vicini amnis) is a problem, producing the deleterious contagion, rather than the continuous resonance, of Vergil's neighbouring hedge in Eclogue 1; its sounds are not so much resonant as competitive, confusing. The re- of resonant is replaced by the ob of obstrepat and obest, and where the prefix re- does occur (respondent, 65) it is unpleasant, competitive. ${ }^{23}$ For Astylus the environment in which poetry is heard must be as mute as possible, allowing an isolated voice to be heard without distortion or addition. Resonance, on the other hand, figures the opposite of a text that is enclosed in itself.

As you can see, I am already turning to the allegorical, and it is time to draw some morals, as we have been invited to do. I have chosen a text that has proven a happy hunting ground for the two main tendencies of English Latin studies, intertextuality and metapoetics. And no one would deny that both approaches are relevant to this text, or that the Eclogues is representative of Roman poetry in that respect. To take metapoetry first. Too often, at least in the English-speaking world, we have been content to treat the mere fact of metapoetry as the Holy Grail. “...And so we see that 
this is poetry about poetry" we conclude with a smile of relief, and leave it at that, as though we already knew what poetry is, and as though the metapoetic reference merely points to it. Metapoetry should be seen as an exploration of what poetry might be, or become, and different poets and works have different things to tell us about it. ${ }^{24}$ As far as the Eclogues are concerned, the insistence that poetry is resonant, and that this implies a locale in which it resonates, draws attention to the way that poetry, avidum auricularum, encourages us to hear and rehear in a different mode, until we hear the sound of sense as Julie Andrews did the sound of music.

And now to intertextuality. In his revelatory study of this phenomenon Stephen Hinds at one point invites us to "reverse the trope" (1998.10-16). Instead of saying, for instance, that memory is really a way of talking about allusion, he suggests that we explore how allusion is a way of talking about memory. Hinds' challenge has not been taken up as much as it deserves to be. ${ }^{25}$ In the Eclogues, I would suggest, intertextuality is one more form of resonance, rather than the ultimate referent of the various forms of echo. So, instead of saying that the language and the phenomenon of acoustic resonance in the Eclogues is a figure of intertextuality, we could think about how intertextuality is a way of figuring resonance (and resonance itself as the essence of poetry).

The Eclogues tell us that a resonant acoustic is intrinsic to song, and this acoustic is a form of hearing. Resonance is a phenomenon that attaches both to utterance and to hearing (the woods learn to resonate Amaryllis (or "Amaryllis") and the copses resonate with the cicadas); it attaches both to voice and to the environment in which it is heard at the same time. We have no difficulty in acknowledging that the backwardlooking intertextual echoes are internal to the Eclogues. It is more difficult to describe how the resonance of Vergil's poetry as manifested, for instance, in Tennyson's lines is not a subsequent act of reception but the environment of the poetry itself. As Shane Butler (2015. 86) remarks, a propos alliteration, we should be aware of the ways that poetry looks forward as well as (allusively) back, "crafting from repetition in poetry a figure for the repetition of poetry". A helpful related phenomenon would be what James Porter has called "prospective classicism", in which an author (Horace would be a prime example) imagines his own work as a classic, looking back on what it will be, a retrospective glance which becomes internal to the work (Porter 2006.60-1).

And finally, back to the sound of music. I am very much aware that the lines of Latin poetry that I read out at the meeting of an international group of European scholars for which this paper was conceived would sound very different when read by others in the same group. It has always puzzled me that, though Latin has been pronounced and performed in very different ways at different times and in different countries, there is general agreement on what sounds good, on the mellifluous and the harsh. The sound of the Eclogues is very important, on that we agree. But on what that sound actually is we have different opinions, or at least practices. So, to adapt and reverse Julie Andrews' words, the world of Latin scholars can't agree on the sound of Vergil's Eclogues but it can agree on the music of (its) sound, and perhaps it takes a resonantly polyglot environment to bring that sound to life. I write this on the day that Britain decides whether or not to remain in the EU. 


\section{BIBLIOGRAPHY}

Ahl F. (1985), Metaformations: Sound and Wordplay in Ovid and Other Classical Poets, Ithaca.

Alpers P. (1996), What is Pastoral?, Chicago and London.

Baraz Y. (2015), "Sound and Silence in Calpurnius Siculus", American Journal of Philology 136: 91-120.

Benjamin W. (1968), Illuminations, New York.

Boyle A. (1977), “Virgil’s Pastoral Echo”, Ramus 6.2: 121-31.

Breed B. (2006) Pastoral Inscriptions: Reading and Writing Virgil's Eclogues, London.

Butler S. (2015), The Ancient Phonograph, New York.

Conte G-B. 1986, The Rhetoric of Imitation: Genre and Poetic Memory in Virgil and Other Latin Poets (translated from the Italian), Ithaca.

Cucchiarelli, A, (2012), Publio Vergilio Marone. Le Bucoliche, Rome.

Damon P. (1961) "Modes of Analogy in Ancient and Medieval Verse" University of California Publications in Classical Philology 15.6: 261-334.

Deremetz A. (1995) Le Miroir des Muses: poétiques de la réflexivité à Rome, Villeneauve d'Ascq.

Desport M. (1941), “L'echo de la nature et la poésie dans les Églogues de Virgile”, Revue des Études Antiques 43: 270-81.

Fabre-Serris J. (2008), Rome, l'Arcadie et la mer des Argonautes. Essai sur la naissance d'une mythologie des origines en Occident, Lille.

Fitzgerald W. (1995), Catullan Provocations: Lyric Poetry and the Drama of Position, Berkeley.

Fitzgerald W. (2007), Martial: the Epigrammatic World, Chicago.

Frye N (1951), Anatomy of Criticism: Four Essays, Princeton.

Gutzwiller K. (1991), Theocritus' Pastoral Analogies, Madison.

Hinds S (1998) Allusion and Intertext: Dynamics of Appropriation in Latin Poetry, Cambridge.

Porter J ed. (2006) Classical Pasts: The Classical Traditions of Greece and Rome, Princeton.

Sebeok T, ed. (1960), Style in Language, Cambridge, Mass.

\section{NOTES}

1. The French title is Melodie du Bonheur, the German Meine Lieder, Meine Träume and the Italian Tutti Insieme Appassionatamente. Further evidence, if such were needed, that music means different things in different cultures!

2. Baraz 2015: 93-6 points out that the parallel between natural and human sound in Theocritus changes into a causal relationship between the two in Vergil.

3. By selecting the bucolic component of Theocritus' Idylls for imitation Vergil founds the genre.

4. On the relation between Lucretius' treatment of the invention of music and the pastoral tradition, see Fabre-Serris 2008.31-40. 
5. It may seem curious that it is specifically the woods that are to produce a resonant locale for song, but Walter Benjamin (1968: 76) also seems to find resonance in the woods when he says this of translation: "Unlike a work of literature, translation does not find itself in the centre of the language forest but on the outside facing the wood ridge; it calls into it without entering, aiming at the single spot where the echo is able to give, in its own language, the reverberation of the work in an alien one."

6. Breed offers a conspectus of scholarly views on echo in the Eclogues as follows: "Echo is a figure both intimately associated with pastoral and wide-ranging in its suggestiveness, whether as metaphor for intertextuality, a symbol of the difficulty of distinguishing between self and other, or a manifestation of language that simply repeats and redoubles itself. Philip Hardie has recently focused on echo as the epitome of pastoral 'plenitude' the marker of a landscape full of human presence" (Breed 2006.74).

7. Similarly, Deremetz 1995.295 finds in Eclogue 6, a locale that resounds with the originary song of Apollo

8. Its only other occurrence in the Eclogues is Ecl. 7.13, eque sacra resonant examina quercu.

9. As an anonymous reader for Dictynna points out, these lines can also be translated taking cicadis as an instrumental ablative: "The copses resound with the rasping song of the cicadas as well as with me". They would then be describing a mixed music.

10. Roman Jakobson's words on the poetic function are relevant here: "The poetic function projects the principle of equivalence of the axis of selection onto the axis of combination" (in Sebeok 1966. 358), with some interesting words on parallelism by Gerard Manley Hopkins on 369. 11. To crown the echo-effect in this line, Vergil recalls Theocritus' $O$ chariess' Amarulli, which itself occurs twice in the Idylls (Id. 3.6; 4.38). As Cucchiarelli observes, ' $x$ is beautiful' is equivalent to 'I love x", so this line may imply the declaration formosa Amaryllis. Compare Propertius 1.18.31: resonent mihi Cynthia (or 'Cynthia') silvae.

12. On analogy as structure in Theocritus, see Gutzwiller 1991: 13-19.

13. Ahl 1985.22: "The testimony of ancient and medieval grammarians rhetoricians and philosophers suggests not only that Greek and Latin poetry resembles Celtic rather than modern English in it use of etymologizing soundplay but also that some of the etymologizing practices in Celtic derive from Latin".

14. On these lines, see Alpers 1996.295-300.

15. Starting with Conte 1986. 60-2, alluded to in Hinds 1998. 3-4.

16. Baraz 2015. 98-9 remarks on the difference between nature's obstructiveness in the earlier lines of Meliboeus' description of Tityrus' farm (46-50) and the paradise of pastoral song that follows. She goes on to find in the earlier lines the seeds of the discordant relation between nature and human song in Calpurnius Siculus' Eclogues.

17. Continuity is stressed in another mode by the fact that this scene recalls the prototype of the locus amoenus in pastoral poetry, Theocritus Id. 7.133-45.

18. Another example of the same phenomenon would be Ecl. 5.81 quae tibi, quae tali reddam pro carmine dona.

19. Interea is echoed, metrically and sonically by aeria, respectively time and place, adverb and adjective.

20. Breed 2006 takes the tension between voice and textuality in the Eclogues as its theme.

21. Somewhat surprisingly to modern ears, cicadas featured as figure for the poet, because of their beautiful song (Theocritus, Id. 1.148, Plato Phaedrus 258e-9d and Callimachus Aetia fr.1.30 (I sing among those who love the song of the cicada, not the donkey).

22. On this aspect of post-Vergilian pastoral, see now Baraz 2015, who builds on Damon's insights. 
23. Baraz 2015.111-2 notes the prominence of ob-compounds in this passage, picking up the obducat of Vergil Ecl. 1.48, the lone example in Vergil's Eclogues of an ob-compound "used to describe how nature interacts with space that is used by people" (98).

24. I have tried to use the concept of metapoetry in this spirit in my study of Catullus (Fitzgerald 1995), in which I argued that the metapoetic dimension of Catullus' work explores the possibilities of poetry as a drama of position between reader and writer in relation to language. Alain Deremetz (1995 287-314) pursues the full and varied resonance of the word deductum to see what its use in the sixth Eclogue has to tell us about poetry.

25. Though it did inspire me to consider, among other things, the ways in which Martial's comparison of his book to a freedman might be thinking about freedmen through the metaphor of the circulating book as much as vice versa (Fitzgerald 2007.95-7).

\section{ABSTRACTS}

This paper examines the sonic world of the Eclogues, arguing that 'resonance' might be a more appropriate term under which to consider it than the more commonly cited 'echo'. It examines not only the characteristic sonic effects of the Eclogues as poetry, but also the importance of a resonant acoustic to the pastoral genre. The discussion of resonance in the Eclogues lead to a reconsideration of current trends in the study of intertextuality and metapoetry as well as the implications of the term resonance for the reception of the Eclogues.

INDEX

Keywords: Vergil, Eclogues, pastoral, echo, resonance, metapoetry, intertextuality, Calpurnius Siculus

\section{AUTHOR}

WILLIAM FITZGERALD

King College London 